\title{
STRATEGI KPU KOTA PEKANBARU DALAM MENINGKATKAN ANGKA PARTISIPASI PEMILIH DALAM PILWAKO TAHUN 2017
}

\author{
Fitri Andriani'), Emeraldy Chatra $^{2)}$, Syahrizal ${ }^{3)}$ \\ 1,2,3 ) Magister Konsentrasi Tata Kelola Pemilu Universitas Andalas, Padang, Indonesia
}

\begin{abstract}
Abstrak
Partisipasi pemilih menjadi salah satu indikator sebuah hasil pemilihan umum dengan derajat legitimasi yang kuat. Angka partisipasi seringkali menjadi acuan bagi penyelenggara pemilu apakah pemilu yang diselenggarakannya memiliki daya Tarik yang kuat kepada warga negara untuk terlibat di dalamnya. Tidak heran jika kemudian KPU sebagai penyelenggara pemilu memandang angka partisipasi sebagai nominal yang akan selalu diusahakan meningkat dari pemilu ke pemilu. Question Researchny adalah bagaimana strategi KPU Kota Pekanbaru dalam meningkatkan angka partisipasi pemilih?.

Pemilihan Walikota dan Wakil Walikota tahun 2017 berjalan dengan lancar dan damai. Firdaus-Ayat Cahyadi keluar sebagai pemenang pesta demokrasi yang diselenggarakan dalam sekali limatahun itu. Dalam Pilwako kali ini angka partisipasi pemilih hanya 51,9\% tentunya ini masih jauh dari angka yang diharapkan dan sudah dipatok oleh KPU RI yaitu 77,5\%. KPU Kota Pekanbaru sudah berupaya semaksimal mungkin untuk mendongkrak angka partisipasi pemilih ini sehingga target nasional tercapai. KPU Kota Pekanbaru menggunakan strategi on dan strategi off. Strategi on adalah dengan memaksimalkan fungsi ICT dan pemanfaatan media social dalam bersosialisasi. Sedangkan strategi off adalah strategi konvensional yang selalu digunakan oleh hampir semua KPU yang ada di Indonesia yaitu dengan cara memasifkan sosialisasi di instansi-instansi, sosialisasi melalui ceramah-ceramah pemuka agama di masjid dan mushallah, sosialisasi ke kampus-kampus dan institusi pendidikan lainnya, sosialisasi di mall-mall, jalan raya, tempat keramian, memaksimalkan fungsi FKUB (Forum Kerukunan Umat Beragama), membuat Focus Discussion Group (FGD), Membuat diskusi-diskusi komunitas seperti Komunitas Buzzer Pekanbaru, MDI, Mahasiswa, iklan dan ajakan di media massa, poster dan baliho yang disebarkan di masyarakat.
\end{abstract}

Key word: KPU Pekanbaru, Pilkada, Partisipasi Pemilih,

*CorrespondenceAddress : andrianif15@yahoo.com

DOI : $10.31604 /$ jips.v6i2.2019.238-252

(C)2019 Fakultas Keguruan \& Ilmu Pendidikan UM-Tapanuli Selatan 
Di dalam negara yang menganut sistem demokrasi, pemilihan umum (pemilu) merupakan satu-satunya mekanisme pergantian kekuasaan yang sah. Pemilu menjamin berlangsungnya rotasi kekuasaan penyelenggara negara. Rotasi kekuasaan inilah yang merupakan hasil dari proses penyelenggaraan pemilu. Pemilu merupakan ajang kontestasi politik lima tahunanyang memberikan ruang bagi keterlibatan rakyat secara langsung dalam menentukan siapa pemimpinnya. Bagaimanapun pemimpin akan menentukan nasib rakyat melalui kebijakan publik dengan berdasarkan ketentuan hukum yang sah. Mereka adalah para penyelenggara negara, pengemban mandat rakyat untuk memastikan kesejahteraan dan terpenuhinya hak-hak rakyat

Melalui penyelenggaraan pemilu, baik presiden dan wakil presiden serta legislatif, harus dimaknai sebagai penyerahan mandat rakyat sebagai pemegang kedaulatan tertinggi. Oleh karena itu, penyelenggaraan pemilu tidak bisa dilepaskan dari peran publik, pemilih dan warga negara. Bagaimanapun rakyat adalah pemilik kedaulatan sesungguhnya. Berdasarkan latar tersebut, peran publik, pemilih dan warga negara tidak bisa diabaikan. Tingkat partisipasi pemilih dalam pemilihan umum adalah salah satu faktor untuk menilai sejauh mana kualitas pemilu itu diselenggarakan. Partisipasi tidak sekadar persoalan seberapa tinggi tingkat pemilih menggunakaan hak pilihnya di bilik suara, tetapi juga sejauh mana penggunaan hak pilih tersebut dilakukan atas kesadaran sebagai pemilih.

Tahun 2017 adalah tahun yang sangat menentukan bagi kemajuan Kota Pekanbaru. Pada tahun ini pula diselenggarakannya hajatan demokrasi Pemilihan Walikota dan Wakil Walikota Pekanbaru. Baik-buruknya Pekanbaru lima tahun kedepan ditentukan pada medio Februari lalu. Masyarakat Pekanbaru yang sudah memiliki hak untuk memilih menyalurkan aspirasi politiknya melalui pemilihan pemimpin yang ditentukan dalam bilik suara. Secara statistic, angka partisipasi pemilih pada Pilwako Pekanbaru tahun 2017 hanya bertenggar pada angka 51,9\% saja, artinya masih jauh dari target yang sudah ditetapkan secara nasional yaitu 77,5\%. Minimnya angka partisipasi tersebut tentunya memiliki alasan yang logis dan wajar diperdebatkan di forum-forum ilmiah yang ada, dan ini biarlah menjadi pekerjaan para akademisi untuk memecahkan teka-teki minusnya partisipasi publik di Kota Bertuah ini.

Namun pada sisi yang lain, ada lembaga Independen bernama KPU Kota Pekanbaru yang sudah berusaha semaksimal mungkin dalam mengelola 
Pemilihan Walikota dan Wakil Walikota Pekanbaru (Pilwako) sehingga menetapkan pasangan Firdaus-Ayat Cahyadi sebagai pemenang Pilwako. Berkaca dari latarbelakang tersebut, maka melahirkan Question Research-nya adalah Bagaimana strategi KPU Kota Pekanbaru dalam meningkatkan partisipasi pemilih pada pilwako tahun 2017?

\section{METODOLOGI}

Penelitian ini menggunakan pendekatan Kualitatif denganMetode Deskriptif. Pengumpulan data dilakukan dengan cara membaca dokumen atau arsip tentang laporan kegiatan Pendidikan Pemilih dan Sosialisasi yang dilakukan oleh KPU Kota Pekanbaru pada Pemilihan Walikota dan Wakil Walikota Pekanbaru Tahun 2017, serta melakukan wawancara dengan informan kunci yang dianggap mampu menggambarkan bagaimana strategi KPU Kota Pekanbaru dalam meningkatkan partisipasi pemilih.

\section{HASIL DAN PEMBAHASAN}

\section{Partisipasi Masyarakat : Tinjauan Teoritis}

Partisipasi pemilih menjadi salah satu indikator sebuah hasil pemilihan umum dengan derajat legitimasi yang kuat. Angka partisipasi seringkali menjadi acuan bagi penyelenggara pemilu apakah pemilu yang diselenggarakannya memiliki daya Tarik yang kuat kepada warga negara untuk terlibat di dalamnya. Tidak heran jika kemudian KPU sebagai penyelenggara pemilu memandang angka partisipasi sebagai nominal yang akan selalu diusahakan meningkat dari pemilu ke pemilu. Beban berat untuk mengusahakan itu secara normatif diletakkan di pundak KPU beserta jajarannya.

Kunci dari peningkatan angka partisipasi ini tentu saja sosialisasi dalam setiap tahapan penyelenggaraan pemilu. Namun dalam konteks pembangunan demokrasi yang lebih luas, maka peningkatan partisipasi publik, khususnya untuk mendongkrak angka partisipasi pemilih, tidak bisa hanya bergantung pada kinerja KPU.

Peningkatan angka partisipasi tentu membutuhkan peran semua pihak. Selain penyelenggara pemilu, masyarakat secara umum, peserta pemilu, pemantau pemilu, serta organisasi masyarakat sipil mesti ikut mensosialisasikan penyelenggaraan dan tahapan pemilu agar publik, terutama pemilih, bisa berpartisipasi dalam pemilu.

Dalam sejarah pemilu Indonesia pascareformasi, Indonesia telah melaksanakan pemilu sebanyak empat kali, termasuk yang terakhir Pemilu 2014.Jika dilihat mulai dari Pemilu 1999, 
angka partisipasi pemilih dalam pemilu legislatif kala itu (presiden masih dipilih oleh MPR), sangatlah tinggi. Partisipasi pemilih dalam Pemilu 1999 mencapai angka 97,7\% (lihat tabel). Artinya, hanya $2,3 \%$ saja pemilih yang tidak memberikan hak suara. Jumlah pemilih yang terdaftar pada Pemilu 1999 adalah 117.815.953 orang. Namun setelah Pemilu 1999, kecenderungan angka partisipasi pemilih justru menurun. Jika berkaca pada data pileg an sich, angka partisipasi pemilih dari Pemilu 1999 ke Pemilu 2004 menurun. Begitu juga dari Pemilu 2004 ke Pemilu 2009, angka pemilih juga mengalami penurunan. Setelah Pemilu 2009, barulah angka partisipasi pemilih meningkat kembali pada Pemilu 2014. Angka partisipasi pemilih pada Pemilu 2009 yang berada pada angka 70,99\%, naik pada Pemilu 2014 menjadi $75,11 \%$.

\section{Membangun Partisipasi Masyarakat dalam Pemilu}

Kegiatan apa saja dan oleh siapa saja yang dapat dikategorikan sebagai partisipasi masyarakat dalam proses penyelenggaraan Pemilu? Setidaktidaknya terdapat 10 (sepuluh) bentuk kegiatan yang dapat dikategorikan sebagai partisipasi unsur masyarakat dalam proses penyelenggaraan Pemilu.

Kesepuluh bentuk partisipasi tersebut adalah sebagai berikut:
Pertama, bekerjasama dengan KPU melaksanakan sosialisasi Pemilu. Sosialisasi Pemilu diartikan sebagai proses transfer pengetahuan tentang apa, bagaimana, kapan dan di mana mengenai tata cara seluruh tahapan Pemilu kepada seluruh pemangku kepentingan Pemilu. Penyelenggara Pemilu lebih menguasai substansinya tidak saja karena KPU yang membuat peraturan pelaksanaan tentang tata cara setiap tahapan Pemilu tetapi juga karena KPU dan aparatnya di daerahlah yang melaksanakan seluruh tata cara Pemilu tersebut.Karena itu kalau unsur organisasi masyarakat sipil melakukan kegiatan sosialisasi Pemilu, maka hendaknya hal itu dilakukan bekerjasama dengan KPU.

Kedua, melaksanakan pendidikan pemilih (voters education) tentang pendaftaran pemilih, visi dan misi serta program Peserta Pemilu/Calon, dan pemungutan dan penghitungan suara. Kegiatan pendidikan pemilih ini dapat dilakukan oleh berbagai Organisasi Masyarakat Sipil (seperti LSM, dan organisasi kemasyarakatan) yang tidak berafiliasi dengan partai politik apapun.

Pendidikan pemilih merupakan proses transfer pengetahuan tentang Pemilu tidak sekedar untuk dapat menjawab pertanyaan apa dan bagaimana Pemilu melainkan terutama untuk 
menjawab pertanyaan mengapa Pemilu. Lingkup tahapan Pemilu yang menjadi fokus pendidikan pemilih juga terbatas, yaitu pendaftaran/pemutahiran daftar pemilih, faktor apa saja yang perlu dipertimbangkan dalam menentukan sikap memilih atau tidak memilih dan memberikan suara kepada siapa, dan pemungutan dan penghitungan suara di TPS. Pengetahuan yang ditransfer mengenai pendaftaran pemilih bukan apa saja yang menjadi syarat menjadi pemilih, bagaimana, kapan dan di mana mendaftarkan diri sebagai pemilih tetapi terutama mengapa mendaftarkan diri sebagai pemilih. Karena pendidikan pemilih menyangkut transfer pengetahuan tentang mengapa mendaftarkan diri sebagai pemilih atau mengapa menggunakan hak pilih, maka kegiatan ini lebih tepat dilakukan oleh unsur-unsur organisasi masyarakat sipil yang tidak berafiliasi dengan Peserta Pemilu daripada oleh Penyelenggara Pemilu. Unsur-unsur organisasi masyarakat sipil lebih leluasa berbicara kritis, termasuk untuk menyatakan tidak perlu menggunakan hak pilih kalau tidak ada partai atau calon yang memenuhi pertimbangan ideal.

Ketiga, keterlibatan anggota partai politik dalam proses pemilihan pengurus partai politik pada berbagai tingkat kepengurusan, proses seleksi calon atau pasangan calon yang akan diajukan untuk pemilihan umum anggota DPR dan DPRD, pemilihan umum presiden dan wakil presiden, dan pemilihan umum kepala daerah dan wakil kepala daerah, dan dalam proses perumusan visi, misi dan program partai politik dalam pemilihan umum anggota DPR dan DPRD, pemilihan umum presiden dan wakil presiden, dan pemilihan umum kepala daerah dan wakil kepala daerah. Keterlibatan anggota partai dalam proses pemilihan pengurus partai, dan melakukan seleksi atas calon atau pasangan calon dilakukan melalui proses pemilihan pendahuluan (primary election), sedangkan keterlibatan anggota partai dalam perumusan visi, misi dan program partai dilakukan melalui musyawarah anggota pada tingkat akar rumput.

Keempat, partisipasi pemilih memberikan suara (casting vote) pada Pemilu.Setiap warga negara yang berhak memilih perlu memastikan diri telah terdaftar sebagai pemilih dalam Daftar Pemilih Tetap (DPT). Untuk memastikan namanya sudah terdaftar dalam DPT, setiap pemilih perlu pula mengecek Daftar Pemilih Sementara yang diumumkan oleh aparat KPU di daerah. Mengajak warga lainnya untuk memastikan namanya atau anggota keluarganya telah terdaftar dalam Daftar Pemilih, mengajak warga yang 
telah terdaftar dalam DPT memberikan suara dengan cara yang sesuai dengan ketentuan, memberikan suara di TPS pada hari pemungutan suara, menyaksikan proses pemungutan dan penghitungan suara di TPS, dan menyampaikan keberatan tentang proses pemungutan dan penghitungan suara di TPS dan rekapitulasi hasil perhitungan suara di atas TPS (apabila terjadi kekeliruan atau penyimpangan) melalui Saksi dari Peserta Pemilu, merupakan contoh partisipasi pemilih memberikan suara.

Kelima, peliputan segala kegiatan yang menyangkut proses penyelenggaraan pemilihan umum yang dilakukan oleh para wartawan dan aparat media lainnya disampaikan melalui pemberitaan atau penyiaran berbagai jenis media massa tentang tahapan Pemilu. Agar rakyat yang berhak memilih dapat menggunakan hak pilihnya secara efektif, mereka harus mengetahui apa dan di mana posisi setiap partai atau calon dalam berbagai isu kebijakan publik. Salah satu peran media massa adalah mendesak setiap partai politik menyatakan posisinya dalam berbagai isu publik. Kedua, media massa baik media cetak maupun elektronik memiliki tanggungjawab melaporkan secara menyeluruh dan akurat tidak saja seluruh tahapan pemilihan umum tetapi terutama apa dan di mana posisi setiap partai politik dan calon dalam berbagai isu kebijakan publik. Pilihan media massa mengenai isu publik yang dijadikan sebagai agenda akan mempengaruhi kepercayaan dan perilaku pemilih. Partisipasi media massa ini akan semakin efektif apabila media massa memegang prinsip objektif dan berimbang (objective and balanced) dalam pemberitaan tentang proses penyelenggaraan Pemilu. Pemberitaan yang objektif berarti memberitakan/menyiarkan berita sesuai dengan fakta apa adanya, pemberitaan yang berimbang (cover all sides) berarti meliput dan menyiarkan berita dari semua pihak.

Pemberitaan tentang Pemilu oleh media massa tidak hanya berperan sebagai pengawas dan pemantau pemilihan umum tetapi juga mendorong partisipasi semua unsur masyarakat dalam penyelenggaraan Pemilu. Pemantauan dan pengawasan oleh media massa tidak hanya menjadi catatan untuk perbaikan pada penyelenggaraan Pemilu yang akan datang tetapi juga menjadi bahan perbaikan bagi penyelenggara dan peserta Pemilu pada proses penyelenggaraan Pemilu yang sedang berlangsung.

Keenam, memberikan dukungan aktif kepada Peserta Pemilu/Calon tertentu. Dukungan aktif dapat dilakukan 
dalam dua bentuk. Pertama, pemberian sumbangan dana kampanye dalam bentuk uang dan/atau materi lainnya kepada Peserta Pemilu/Calon sesuai dengan ketentuan yang berlaku. Dan kedua, keikut-sertaan dalam pengorganisasian kampanye Pemilu baik sebagai unsur pengelola kampanye (seperti Bagian Keamanan, Petugas yang memastikan pemasangan alat peraga di tempat strategik, dan membagikan leaflet) maupun sebagai warga yang menghadiri satu atau lebih bentuk kampanye Peserta Pemilu/Calon tertentu.

Ketujuh, mengajak para pemilih lainnya untuk mendukung atau menyatakan keberatan atas alternatif kebijakan yang ditawarkan oleh Penyelenggara Pemilu ataupun oleh Peserta Pemilu/Calon tertentu. Mengajak dan meyakinkan para pemilih ataupun unsur organisasi masyarakat sipil untuk meminta KPU mengoreksi peraturan pelaksanaan Pemilu yang dipandang bertentangan dengan undang-undang merupakan salah satu contoh partisipasi.

Kedelapan, menyampaikan pengaduan tentang dugaan pelanggaran Administrasi Pemilu, Pidana Pemilu, dan Kode Etik Penyelenggara Pemilu kepada institusi yang berwenang. Setidaknya diperlukan tiga persyaratan, yaitu minat dan perhatian tentang Pemilu, kesadaran tentang pentingnya semua pihak menaati seluruh ketentuan yang mengatur Pemilu untuk menciptakan Pemilu yang adil dan berlejitimasi, dan pengetahuan/informasi tentang peraturan perundangundangan yang mengatur Pemilu. Warga masyarakat yang memiliki ketiga persyaratan ini akan dengan mudah memantau pelaksanaan peraturan perundang-undangan yang mengatur Pemilu tidak hanya karena mampu membedakan tindakan yang termasuk kategori pelanggaran Ketentuan Administrasi Pemilu dari tindakan yang termasuk pelanggaran Ketentuan Pidana Pemilu, ataupun Kode Etik Penyelenggara Pemilu tetapi juga mengetahui bagaimana menyampaikan pengaduan dan kepada instansi apa pengaduan itu disampaikan.

Kesembilan, melakukan survey atas persepsi atau pendapat pemilih mengenai Peserta Pemilu/Calon dan menyebarluaskan hasilnya kepada masyarakat umum. Kegiatan survey atau jajak pendapat pemilih mengenai Peserta Pemilu dan Calon tidak hanya dilakukan oleh berbagai lembaga yang bergerak dalam kegiatan penelitian (seperti lembaga kajian dan LSM) tetapi juga media massa.

Dan kesepuluh, melaksanakan perhitungan cepat atas hasil penghitungan suara di TPS yang menjadi sampel untuk 
memperkirakan kecenderungan hasil

Pemilu (Quick Count). Kegiatan ini dilakukan tidak hanya oleh berbagai lembaga yang bergerak dalam kegiatan penelitian tetapi juga media massa. Hasil perhitungan cepat atas sekian persen dari jumlah TPS ini tidak hanya untuk memenuhi rasa ingin tahu publik secara cepat tetapi juga sebagai pembanding terhadap hasil Pemilu yang secara resmi ditetapkan dan diumumkan oleh penyelenggara Pemilu. Perhitungan cepat yang dilakukan dengan metode yang tepat dan akurat, berguna sebagai instrument menjamin integritas hasil Pemilu.

Dalam pemilu di era Orde Baru, partisipasi pemilih relatif tinggi karena ada dimensi mobilisasi yang sudah dimainkan oleh rezim sepanjang tiga dekade lebih. Partisipasi pemilih dalam proses penyelenggaraan pemilu tidak hanya bisa dilihat ketika masyarakat pemilih datang ke TPS untuk memberikan suaranya. Tetapi lebih dari itu, keterlibatan masyarakat untuk turut berpartisipasi dalam seluruh tahapan pemilu seperti melaporkan adanya kecurangan pemilu, turut memantau proses rekapitulasi penghitungan suara, mendukung salah satu kandidat, melakukan survey tentang pemilu, juga merupakan bagian dari bentuk partisipasi masyarakat yang penting dalam proses penyelenggaraan pemilu. Salah satu hal yang selalu ditunggu dan dihitung selain hasil pemilu adalah angka partisipasi pemilih di dalam penyelenggaraan pemilu. Angka partisipasi pemilih, setidaknya akan menggambarkan sejauh mana partisipasi politik warga dalam kontestasi suatu pemilu. Jika ingin dilihat dari sisi lain, angka partisipasi pemilih ini juga akan menjelaskan kekuatan legitimasi dari orang yang terpilih melalui proses pemilu yang dilakukan. Karena pada hakikatnya, proses pemilu adalah bentuk penyerahan mandat dari pemilih kepada yang dipilih, untuk mewujudkan kesejahteraan bersama.

Berangkat dari itu, tingkat partisipasi pemilih mestinya menjadi entitas penting yang mesti dijaga dan ditingkatkan di dalam penyelenggaraan pemilu. Mengapa peningkatan angka partisipasi pemilih menjadi penting untuk diupayakan? Sebab tingginya angka partisipasi pemilih menjadi potret pelaksanaan demokrasi yang berkualitas.

Kecenderungan menurunnya tingkat partisipasi pemilih, khususnya dalam empat pemilu terakhir pascareformasi, adalah pekerjaan besar bagi demokrasi di Indonesia. Indikasi penurunan ini sudah terasa di Pemilu 2004 dan Pemilu 2009 serta dalam pemilihan kepala daerah di berbagai wilayah, dimana tingkat partisipasi pemilih terlihat 
semakin rendah dibandingkan pada Pemilu 1999. Penurunan ini tentu berdampak secara politik pada legitimasi hasil pemilu itu sendiri, meskipun tidak menjadi problem dalam prosedural demokrasi.

Partisipasi pemilih juga terekam menjadi problem besar bagi demokrasi di Indonesia. Dalam Indeks Demokrasi Indonesia, aspek hak-hak politik (yang di dalamnya terkait hak memilih dan dipilih) ada kecenderungan mempunyai indeks yang paling rendah dibandingkan dengan dua aspek lainnya, yakni kebebasan sipil dan lembaga demokrasi. Hal ini menunjukkan bahwa hak politik terkait hak pilih di Indonesia masih berada dalam kondisi yang lebih buruk dibandingkan dua aspek tersebut. Selain itu, hak politik ini cenderung mengalami penurunan. Pada Indeks Demokrasi tahun 2013, misalnya, nilai kebebasan sipil tercatat 79,00, naik dari tahun 2012 yang hanya 77,94 . Sedangkan untuk aspek hak politik, turun tipis menjadi 46,26 jika dibandingkan tahun 2012 yang mencapai 46,33. Dan untuk aspek lembaga demokrasi, terjadi peningkatan dari 69,28 di 2012 menjadi 72,11 di 20133.

Lemahnya pemenuhan hak-hak politik, terutama terkait hak pilih terakam dalam catatan pemilu di Indonesia. Hal ini terlihat dari kecenderungan penurunan angka partisipasi pemilih di pemilu. Penurunan ini sekaligus diikuti oleh peningkatan jumlah pemilih yang tidak menggunakan hak pilihnya atau "golput".

\section{Partisipasi dan Legitimasi}

Partisipasi pemilih dalam pemilu menjadi penting karena akan berdampak secara politis terhadap legitimasi sebuah pemerintahan yang dihasilkan. Jika sebuah pemilu hanya diikuti oleh separuh dari jumlah pemilih, tentu dari pemilih yang menggunakan hak pilihnya tersebut tidak semuanya memilih satu pilihan politik yang sama. Legitimasi adalah syarat mutlak yang secara politik turut menentukan kuat tidaknya atau lemah tidaknya sebuah pemerintahan.

Partisipasi politik tidak sekadar persoalan dari sisi pemilih menggunakan hak pilihnya saat pemilu di bilik suara, tetapi juga bagaimana publik berperan dalam menciptakan proses pemilu yang kredibel dan bersih melalui keterlibatan dalam pengawasan pemilu sebagai bagian kontrol terhadap penyelenggaraan pemilu itu sendiri. Dalam konteks inilah kemudian partisipasi masyarakat menjadi penting untuk menciptakan kualitas pemilu yang baik. Pengawasan pemilu diadakan agar kedaulatan rakyat yang diwujudkan dalam hak pilih warga negara bisa tersalurkan dengan sebenarnya, tanpa manipulasi dan kecurangan. 
Pengawasan dalam pemilu itu dilakukan dalam seluruh tahapan, baik perencanaan, persiapan, pelaksanaan, dan evaluasi. Semuanya merupakan bagian penting yang tidak terpisahkan untuk memastikan terciptanya pemilu yang fair. Pelanggaran pemilu tidak hanya terjadi di tingkat pelaksanaan lapangan, tetapi dalam beberapa kasus juga terjadi di tingkat perencanaan dan persiapan. Indikasi pelanggaran atau kecurangan bisa dilihat dari beberapa regulasi dan tahapan pemilu, baik sebelum maupun setelah pelaksanaan pemilu.

\section{Good Practices: Peningkatan Partisipasi Pemilih dalam Pemungutan Suara}

Salah satu cara yang dapat ditempuh untuk meningkatkan partisipasi pemilih dalam menggunakan hak pilihnya adalah membangkitkan minat pemilih pemula terhadap pemilihan umum. Berdasarkan perhitungan KPU terdapat sebanyak 14 juta pemilih pemula (yang akan berusia 17 tahun pada tanggal 9 April 2014 sampai 20 tahun). Apabila pemilih pemula digabung dengan pemilih muda (yang berusia 20 sampai 30 tahun) yang jumlahnya mencapai 45.6 juta, maka pendekatan terhadap pemilih muda usia ini akan sangat strategik tidak saja karena jumlahnya mencapai hampir 60 juta tetapi juga karena mereka adalah generasi muda. KPU perlu melakukan sosialisasi tata cara pemilihan umum dengan metode dan media yang sesuai dengan karakteristik generasi muda. Berbagai Organisasi Masyarakat Sipil juga perlu melakukan pendidikan pemilih kepada generasi muda dengan metode, media, dan substansi yang sesuai dengan generasi muda sehingga generasi muda tidak hanya menggunakan hak pilihnya tetapi juga memiliki sejumlah pertimbangan dan alasan tidak hanya untuk memberikan suara tetapi juga partai politik dan/atau nama calon yang dipilih. Partai politik juga perlu melakukan kampanye cerdas bagi generasi muda tersebut sehingga mereka juga berpartisipasi dalam proses penyelenggaraan pemilihan umum.

Untuk menjamin pemilih terdaftar menggunakan hak pilihnya, negara melalui undang-undang perlu menjamin kemudahan bagi pemilih pada umumnya, dan khususnya kepada pemilih yang karena sesuatu hal tidak dapat memberikan suara di TPS pada hari pemungutan suara. Kemudahan bagi pemilih pada umumnya perlu dijamin dalam bentuk penawaran alternatif pilihan pemberian suara yang sederhana, singkat dan jelas: memberikan suara kepada satu partai politik Peserta Pemilu atau kepada satu nama calon. Alternatif pilihan pemberian suara yang kompleks niscaya tidak saja membingungkan pemilih untuk memahaminya sehingga 
kemungkinan surat suara tidak sah semakin besar tetapi juga membingungkan Ketua dan Anggota KPPS sehingga keliru dalam melakukan sertifikasi atas hasil pelaksanaan pemungutan suara.

Pemberian kesempatan kepada pemilih yang karena sesuatu hal tidak dapat hadir memberikan suara di TPS pada hari pemungutan suara dapat dijamin dalam bentuk memberikan suara paling cepat 7 (tujuh) hari dan paling lambat sehari sebelum hari pemungutan suara (absentee voting) dengan menyerahkan surat suara yang sudah dicoblos secara tertutup kepada Ketua KPPS, atau, mengirimkan surat suara yang sudah dicoblos melalui kantor pos kepada Ketua KPPS (mail voting). Surat Suara yang sudah dicoblos itu akan dibuka pada saat penghitungan suara di TPS. Selain itu, jaminan kemudahan juga dapat diberikan dalam bentuk tempat pemungutan suara yang bergerak atau petugas pemungutan suara mendatangani pemilih yang karena sesuatu hal tidak dapat mendatangani TPS (mobile polling stations), seperti pemilih yang sudah lanjut usia, pemilih yang lumpuh, pemilih yang sakit di rumah, atau penyandang cacat; pembentukan TPS khusus kepada pemilih yang karena sakit harus rawat inap di rumah sakit atau karena tengah menjalani masa tahanan harus berada di lembaga pemasyarakatan (special polling stations); dan tata letak TPS yang menjamin akses yang memadai bagi penyandang cacat yang menggunakan kursi roda atau menyediakan sarana pemberian suara (seperti penggunaan template surat suara dengan huruf braille) bagi penyandang cacat tuna netra.

\section{Partisipasi Pemilih: Bahasa Angka}

\section{Dalam Pilwako Pekanbaru}

$$
\text { Pemilihan Walikota yang }
$$

berlangsung tahun 2017 semalam berjalan dengan lancer, damai tanpa ada riak-riak yang bisa mengotori arti dari sebuah demokrasi. Pesta demokrasi yang diselenggarakan dalam limatahun itu diikuti oleh lima pasangan calon dengan gambaran perolehan suara sebagai berikut:

Tabel 1: Perolehan Suara

\begin{tabular}{|c|c|c|}
\hline Pasangan Calon & $\begin{array}{l}\text { Perolehan } \\
\text { Suara }\end{array}$ & Persentase \\
\hline $\begin{array}{l}\text { DR. H. Syahril, S.Pd, MM } \\
\text { dan H. Said Zohrin, SH, } \\
\text { MH }\end{array}$ & 22.149 & $7.78 \%$ \\
\hline $\begin{array}{l}\text { H. Herman Nazar, S.H ., } \\
\text { M.Si dan Defi Warman, } \\
\text { S.Pd., M.Pd }\end{array}$ & 46.472 & $16.33 \%$ \\
\hline $\begin{array}{l}\text { Dr. H. Firdaus, ST, MT } \\
\text { dan H. Ayat Cahyadi, S.Si }\end{array}$ & 94.118 & $33.07 \%$ \\
\hline $\begin{array}{l}\text { DR. H. M. Ramli, S.E., } \\
\text { M.Si. dan dr. Irvan } \\
\text { Herman }\end{array}$ & 59.613 & $20.95 \%$ \\
\hline $\begin{array}{l}\text { Drs. H. Dastrayani Bibra, } \\
\text { M.Si dan H. Said Usman } \\
\text { Abdullah }\end{array}$ & 62.249 & $21.87 \%$ \\
\hline Total & 284.601 & $100 \%$ \\
\hline
\end{tabular}

Sumber : diolah dari KPU RI, 2017

Maka dalam percaturan politik Ibu

Kota Provinsi Riau tersebut Pasangan Firdaus-Ayat Cahyadi keluar sebagai 
pemenang dan berhasil mendapatkan hati rakyat dengan perolehan suara sebesar 33,07 \% mengungguli dari empat pasang calon lainnya yang juga ikut bertarung dalam Pemilihan Walikota dan Wakil Walikota 2017 lalu.

Selanjutnya, dalam pilwako tersebut juga kami paparkan data tentang partisipasi pemilih yang menjadi core artikel ini sebagai mana tertuang dalam bentuk table dibawah ini :

Tabel 2: Pemilih dan pengguna hak pilih

\begin{tabular}{|l|l|l|l|}
\hline & Laki-Laki & Perempuan & Total \\
\hline Pemilih & 265.016 & 267.027 & 568.744 \\
\hline $\begin{array}{l}\text { Pengguna } \\
\text { Hak Pilih }\end{array}$ & 129.398 & 146.486 & 295.402 \\
\hline
\end{tabular}

Sumber : diolah dari KPU RI, 2017

Tabel 3: Partisipasi Pemilih

\begin{tabular}{|l|l|l|l|}
\hline & Laki-Laki & Perempuan & $\begin{array}{l}\text { Total } \\
\text { Partisipasi }\end{array}$ \\
\hline Memilih & $48,8 \%$ & $54,9 \%$ & $51,9 \%$ \\
\hline $\begin{array}{l}\text { Tidak } \\
\text { Memilih }\end{array}$ & $51,2 \%$ & $45,1 \%$ & $48,1 \%$ \\
\hline & & & \\
\hline
\end{tabular}

Sumber : diolah dari KPU RI, 2017

Berdasarkan paparan dari table diatas maka dapat diketahu bahwa angka partisipasi masyarakat dalam menyalurkan hak pilihnya ada sebesar $51,9 \%$ tentunya ini masih jauh dari target nasional yang sudah terlanjur dipatok pada angka $77,5 \%$

\section{Strategi Meningkatkan Partisipasi Pemilih di Pilwako Pekanbaru}

Keyakinan akan pemilu sebagai instrumen terpenting bagi demokratisasi memperoleh legitimasi yang kuat dari Samuel P. Huntington dalam buku The Third Wave of Demoratization in The Late Twentieth Century (1993). Huntington mendefinisikan demokrasi dengan merujuk pada pendapat Joseph Schumpeter yakni bahwa demokrasi secara prosedural dengan pemilu sebagai esensi demokrasi. Akan tetapi, Huntington segera menambahkan bahwa sistem demokrasi tak cukup hanya dengan pemilu tapi juga dilengkapi dengan kebebasan berpendapat, berkumpul, dan pers. Proses penyelenggaraan pemilu yang sudah dilandasakan asas-asas pemilihan yang ada masih harus dibumbui dengan kebebasan berpendapat yang lebih terbuka.

Pelaksanaan Pilkada adalah bagian dari langkah mewujudkan demokrasi secara menyeluruh. Pelaksanaan Pilkada yang digelar secara langsung adalah salah satu perwujudan komitmen negara demokrasi sebagaimana yang telah digariskan dalam konstitusi. Membangun sistem pemilu dibutuhkan nilai etika. Dengan berbagai teori yang kita miliki dan pengalaman perpolitikan di Indonesia selama ini dapat kita gunakan untuk membangun demokrasi dengan 
menggunakan prinsip nilai yang kita yakini bersama. Kekuasaan tanpa etika akan menjadi lemah karena tidak ada legitimasi, maka kekuasaan harus dengan etika supaya bisa dikontrol

Partisipasi pemilih dalam pemilu menjadi penting karena akan berdampak secara politis terhadap legitimasi sebuah pemerintahan yang dihasilkan. Jika sebuah pemilu hanya diikuti oleh separuh dari jumlah pemilih, tentu dari pemilih yang menggunakan hak pilihnya tersebut tidak semuanya memilih satu pilihan politik yang sama. Legitimasi adalah syarat mutlak yang secara politik turut menentukan kuat tidaknya atau lemah tidaknya sebuah pemerintahan.

Dalam meningkatkan angka partisipasi pemilih sesunggunya KPU Kota Pekanbaru sudah melakukan bergagai strategi dan cara agar angka partisipasinya dari pemilu ke pemilu bisa terdongkrak naik. Dalam Laporan penyelenggaraan pemilu Kota Pekanbaru, KPU Kota Pekanbaru memiliki strategi peningkatan angka partisipasi dalam dua bentuk : Pertama, Strategi On. Strategi ini adalah sebuah upaya untuk menumbuhkan kesadaran masyarakat sehingga angka partisipasi pemilih itu naik dengan cara pendekatan online. Strategi ini adalah dengan cara memaksimalkan penggunaan media Information, Communication and Technology
(ICT) seperti memaksimalkan fungsi website resmi, memasifkan ajakan pemilu melalui akun instagram (@kpu_pekanbaru), melalui facebook dan twitter resmi KPU Kota Pekanbaru beserta streaming youtube.

Kedua, Strategi off, yaitu upaya menumbukan kesadaran masyarakat akan arti penting pemilu dalam tatanan hidup berbangsa dan bernegara agar meningkatnya angka partisipasi pemilih dengan strategi off yaitu lawan dari strategi on. Strategi ini adalah strategi konvensional yang selalu digunakan oleh hamper semua KPU yang ada di Indonesia yaitu dengan cara memasifkan sosialisasi di instansi-instansi, sosialisasi melalui ceramah-ceramah pemuka agama di masjid dan mushallah, sosialisasi ke kampus-kampus dan institusi pendidikan lainnya, sosialisasi di mall-mall, jalan raya, tempat keramian, memaksimalkan fungsi FKUB (Forum Kerukunan Umat Beragama), membuat Focus Discussion Group (FGD), Membuat diskusi-diskusi komunitas seperti Komunitas Buzzer Pekanbaru, MDI, Mahasiswa, iklan dan ajakan di media massa, poster dan baliho yang disebarkan di masyarakat.

\section{Simpulan}

Pemilihan Walikota dan Wakil Walikota tahun 2017 berjalan dengan lancar dan damai. Firdaus-Ayat Cahyadi 
keluar sebagai pemenang pesta demokrasi yang diselenggarakan dalam sekali limatahun itu. Dalam Pilwako kali ini angka partisipasi pemilih hanya 51,9\% tentunya ini masih jauh dari angka yang diharapkan dan sudah dipatok oleh KPU RI yaitu 77,5\%. KPU Kota Pekanbaru sudah berupaya semaksimal mungkin untuk mendongkrak angka partisipasi pemilih ini sehingga target nasional tercapai. KPU Kota Pekanbaru menggunakan strategi on dan strategi off. Strategi on adalah dengan memaksimalkan fungsi ICT dan pemanfaatan media social dalam bersoisalisasi. Sedangkan strategi off adalah strategi konvensional yang selalu digunakan oleh hamper semua KPU yang ada di Indonesia yaitu dengan cara memasifkan sosialisasi di instansi-instansi, sosialisasi melalui ceramah-ceramah pemuka agama di masjid dan mushallah, sosialisasi ke kampus-kampus dan institusi pendidikan lainnya, sosialisasi di mall-mall, jalan raya, tempat keramian, memaksimalkan fungsi FKUB (Forum Kerukunan Umat Beragama), membuat Focus Discussion Group (FGD), Membuat diskusi-diskusi komunitas seperti Komunitas Buzzer Pekanbaru, MDI, Mahasiswa, iklan dan ajakan di media massa, poster dan baliho yang disebarkan di masyarakat.
Dalam diskusi kali ini, penulis memberikan rekomendasi yaitu perlunya meneliti factor-faktor yang mempengaruhi rendahnya angka partisipasi masyarakat, kemudian harus adanya terobosanterobosan baru yang tidak menoton yang dilakukan oleh KPU Kota Pekanbaru dalam hal sosialisasi dan meningkatkan angka partisipasi pemilih.

\section{Daftar Pustaka}

Andrew Ellis, et al., Engaging the Electorate Inhabitants to Promote Voter Turnout from Around the World, (Stockholm: International IDEA, 2006).

David H. Hopman, Christian ElmelundPrastekaer, Erik Albaek, Rens Vligenthart, dan Claes $H$. de Vreese, Party Media Agenda-setting: How Parties Influence Election News Coverage, dalam Party Politics, Volume 18, Nomor 2 , edisi Maret 2012, h. 173-192.

Husein, Harun. (2014). Pemilu Indonesia, Fakta, Angka, Analisis, dan Studi Banding. Jakarta: Perkumpulan untuk Pemilu dan Demokrasi

Civic and Voter Education, ACE The Electoral Knowledge Network; dan Yerevan, The Concepts of Civic Education, Electoral Education and Voter Awareness, (Stockhold, Swedia: Internasional IDEA, 2006). Sebagaimana dikutip oleh Surbakti, Ramlan., \& Supriyanto, Didik. (2013). Partisipasi Warga Masyarakat Dalam Proses Penyelenggaran Pemilihan Umum. Jakarta: Kemitraan bagi Pembaruan Tata Pemerintahan.

John H. Aldrich and Kathleen M. McGraw, Eds., Improving Public Opinion Surveys: Interdisciplinary Innovation and the American National Election Studies, (Princeton: Princeton University Press, 2012).

Indeks Demokrasi Indonesia yang diterbitkan atas kerjasama Bappenas, Kementerian Dalam Negeri, BPS, dan UNDP, 2013 
Junaidi, Veri. (2013). Pelibatan dan Partisipasi Masyarakat dalam Pengawasan Pemilu. Jakarta: Perkumpulan untuk Pemilu dan Demokrasi (Perludem)

Kompas. Pemilih Pemula Diincar Parpol, edisi Kamis 24 Oktober 2013, h. 2.

Mar'iyah, Chusnul. 2012. Menggugat Politik Dinasti dalam Pemerintahan Indonesia, Jurnal Ilmu Pemerintahan, Hal, 64

Melissa Estok, Neil Nevitte dan Glen Cowan, The Quick Count and Election Observation: An NDI Guide for Civil Organizations and Political Parties, (Washington, DC: NDI for International Affairs, 2002).

Ramadhanil, Fadli., Junaidi, Veri., \& Ibrohim. (2015). Desain Partisipasi Masyarakat Dalam Pemantauan Pemilu. Jakarta: Kemitraan bagi Pembaruan Tata Pemerintahan di Indonesia atas kerjasama dengan Perkumpulan untuk Pemilu dan Demokrasi (Perludem).

Rafael Lopez Pinto dan Maria Gratschew, Voter Registration and Inclusive Democracy: Analyzing Registration Practice Worldwide, tanpa penerbit dan tahun;

Samuel P. Huntington, The Third Wave: Democratization in the Late. Twentieth Century (University of Oklahoma Press, 1991 - first paperback printing, 1993)

Surbakti, Ramlan \& Karim, Abdul Gaffar. (2014). Integritas Pemilu 2014; Kajian Pelanggaran, Kekerasan, dan Penyelahgunaan Uang pada Pemilu 2014. Jakarta, Kemitraan Bagi Pembaruan Tata Pemerintah

Surbakti, Ramlan., \& Supriyanto, Didik. (2013). Partisipasi Warga Masyarakat Dalam Proses Penyelenggaran Pemilihan Umum. Jakarta: Kemitraan bagi Pembaruan Tata Pemerintahan.

Surbakti, Ramlan dan Supriyanto, Didik. 2013. Seri Demokrasi Elektoral Buku 12. Partisipasi Warga Masyarakat dalam Proses Penyelenggaraan Pemilihan Umum. Jakarta: Kemitraan bagi Pembaruan Tata Pemerintahan. Diaksesdari: http://kemitraan.or.id/sites/default/fil es/Seri\%20demokrasi\%20elektoral\%2 $\underline{0120 . p d f}$
Thomas Patterson, The Mass Media and Election, (New York: Praeger Publishers, 1980), Stanley Kelly, Jr., Election and the Media, dan Media in Election Campaign, ACE The Electoral Knowledge Network.

Tribunpekanbaru.com. Partisipasi Rendah di Pilwako, KPU Pekanbaru Komitmen Akan Berupaya Tingkatkan di Pilkada 2018, http://pekanbaru.tribunnews.com/201 7/10/29/partisipasi-rendah-dipilwako-kpu-pekanbaru-komitmenakan-berupaya-tingkatkan-di-pilkada2018. Diakses, 29 Mei 2018.

Undang-Undang Dasar Negara Republik Indonesia Tahun 1945

Undang-Undang Nomor 8 Tahun 2012 tentang Pemilu Anggota DPR, DPD dan DPRD.

Willian Cross dan Andre Blais, Who Selects the Party Leader?, dalam Party Politics, Volume 18, Nomor 2, edisi Maret 2012, h. 127-150. 